\title{
The heart of pediatric radiology
}

\section{Richard B. Gunderman ${ }^{1}$}

Received: 14 July 2019 /Revised: 14 July 2019 / Accepted: 6 August 2019/Published online: 14 August 2019

(C) Springer-Verlag GmbH Germany, part of Springer Nature 2019

We all know that preparing to care for children as a pediatric radiologist requires considerable knowledge, skill and experience. It also takes time - a typical pediatric radiologist will have spent 4 years in medical school, 5 years in radiology residency, and another year or 2 in fellowship. Some have even completed other residencies, such as 3 years of general pediatrics.

Less clear is the fact that in addition to excellences of cognition, technique and judgment, pediatric radiology requires excellences of the heart, which we neglect at our patients' and our own peril. In fact, to become the best pediatric radiologists we are capable of being, we must be prepared to have our hearts broken. It is only when are hearts have been broken that they can be remade, deepening our understanding and compassion for the children we serve.

We human beings have not always cared well for our children. At many points in human history, children were seen as a threat or a liability. The ancient Greek Spartans required that babies born with deformities be left to die of exposure. Even today, it is common to speak of the immense cost of raising a child, currently estimated by the U.S. Department of Agriculture at $\$ 234,000$ [1].

Children have also been treated as property. Ancient Roman law considered them a form of chattel. And more recently, children have been exploited as laborers, often to the great detriment of their health and well-being.

For example, in late 18th and early 19th centuries in England, young boys were employed as chimney sweeps, often jammed up into flues against their will. Some harms were immediate, such as asphyxiation or immolation. Others took longer to manifest. The first occupational cancer, a form of scrotal carcinoma,

Richard B. Gunderman

rbgunder@iu.edu

1 Department of Radiology, Indiana University, 702 North Barnhill Drive, Room 1053, Indianapolis, IN 46202, USA was identified in 1775 by surgeon Percivall Pott among chimney sweeps [2]. Of their plight, Potts wrote:

The fate of these people seems peculiarly hard ... they are treated with great brutality ... they are thrust up narrow and sometimes hot chimnies [sic], where they are bruised, burned, and almost suffocated; and when they get to puberty they become ... liable to a most noisome, painful and fatal disease.

To his credit, Pott's extended discussion of the "chimnie sweep's cancer" offers not only an excellent clinical description of the lesion and its occupational association, but also inspires outrage at such exploitation and sympathy for its young victims.

A person who knew much less about medicine but far more about the human heart was the poet William Blake, whose masterpieces "Songs of Innocence" (1789) and "Songs of Experience" (1794) each contain a poem titled "The Chimney Sweeper" [3]. Born in 1757, Blake spent nearly his entire life in London. Leaving school at age 10, he showed early talent for drawing, and eventually began working as an engraver. Regarded by some of his contemporaries as mad, he sold fewer than 50 copies of "Songs," his most famous work, yet he is now widely regarded as the greatest poet-artist in the English language.

To understand how Blake's words can remake our hearts, enabling us to become more understanding and compassionate pediatric radiologists and human beings, we must hear his words. The six stanzas of his first "The Chimney Sweeper" read as follows:

When my mother died I was very young,

And my father sold me while yet my tongue Could scarcely cry "'weep! 'weep! 'weep! 'weep!"

So your chimneys I sweep \& in soot I sleep.

There's little Tom Dacre, who cried when his head That curled like a lamb's back, was shaved, so I said,

"Hush, Tom! never mind it, for when your head's bare, 
You know that the soot cannot spoil your white hair."

And so he was quiet, $\&$ that very night,

As Tom was a-sleeping he had such a sight!

That thousands of sweepers, Dick, Joe, Ned, \& Jack,

Were all of them locked up in coffins of black;

And by came an Angel who had a bright key,

And he opened the coffins \& set them all free;

Then down a green plain, leaping, laughing they run,

And wash in a river and shine in the Sun.

Then naked \& white, all their bags left behind,

They rise upon clouds, and sport in the wind.

And the Angel told Tom, if he'd be a good boy,

He'd have God for his father \& never want joy.

And so Tom awoke; and we rose in the dark

And got with our bags \& our brushes to work.

Though the morning was cold, Tom was happy \& warm;

So if all do their duty, they need not fear harm.

What does Blake do in this poem? By speaking as a child, he gives voice to the voiceless, a child orphaned by his mother, abandoned by his father, and so young that he is scarcely able to offer an articulate sound. He levels an accusation at us, the readers, for it is our chimney that the narrator sweeps, making us complicit in his sooty existence. Most significantly, he gives the chimney sweeps proper names - Tom Dacre, Dick, Joe, Ned and Jack. He reminds us that we should think twice before talking of "children" and instead recognize the distinctive identity of each little child.

Blake implicates us in justifying Tom's suffering, both to him and especially to ourselves. We say that shaving his head spares his white hair - that to avoid despoiling it, we rid him of it. A child may need to be held in place or even subjected to pain to complete a radiology procedure, but we should never presume to turn a deaf ear to a child's cries.

Although the young cannot speak for themselves, the suffering of a child is no less real and counts for every bit as much as that of any adult. The moral significance of agony is not necessarily reflected by the voices raised against it.

It would be comforting to suppose that the image of thousands of sweepers locked in coffins is merely a dream, but we know from the accounts of Pott and others that it was anything but. Boys sometimes as young as 4 years were injured, poisoned and killed simply because they were exploitable.

It is not the burials but the images of children leaping, laughing, and shining that constitutes the dream. The children's plight is so desperate that their only hope of liberation is death. Only mortality can set them free.

The first stanzas of the poem, with the chimney's soot and Tom's hair, are all black and white, but once the angel sets the children free, a technicolor world opens up, with a green plane and sunlight. Tom finds himself high in the clouds, where he learns that to find joy, all he must do is "be a good boy."
Yet when Tom awakes and arises, the world is still dark and gray. He may believe that all will be well if he does his duty, but we know otherwise. What, Blake asks in an implicit yet also pointed way, are we going to do about it?

Blake never heard of pediatrics, radiology or pediatric radiology, but his words in effect challenge every pediatric radiologist to think and feel beyond our job descriptions, and to function not just as imagers and proceduralists but as advocates for children. Only if we know the plight of Tom, Dick, Joe, Ned and Jack can we call others to witness it, and only insofar as we ourselves are moved to action can we call others to do the same. Blake doesn't tell us what to do, but his narrative provides us the means to fully engage our moral imaginations.

Blake's second "The Chimney Sweep," by painting an even bleaker picture of indifference and hypocrisy, issues an even more poignant call. Its three stanzas read:

A little black thing among the snow,

Crying "weep! 'weep!" in notes of woe!

"Where are thy father and mother? say?"

"They are both gone up to the church to pray.

Because I was happy upon the heath,

And smil'd among the winter's snow,

They clothed me in the clothes of death,

And taught me to sing the notes of woe.

And because I am happy and dance and sing,

They think they have done me no injury,

And are gone to praise God and his Priest and King,

Who make up a heaven of our misery."

Again, Blake presents us with a black and white world, "a little black thing among the snow." Again, this little black thing - darkened not by nature but by abuse - is barely articulate, merely plaintively crying, "Weep! Weep!"

Yet in this case, his father and mother are not dead or even dead to him. Instead they have gone to church, to pray. We might suppose that we fully discharge our professional and moral responsibility to children merely by providing highquality, safe, cost-effective care, but what if we, too, resemble the pious parents who have gone to church?

Instead of helping the children, the parents go to church to say their prayers. They do not act to relieve the conditions of suffering. Do we, like the parents, go to our reading rooms and procedure suites to dictate our reports but fail to see the real significance of what lies all too visible right in front of our noses? Do we, as pediatric radiologists, physicians and officers of the public health, recognize that our professional responsibility extends beyond diagnosis and treatment to addressing the underlying roots of disease and injury?

How many pediatric skeletal surveys have we dutifully interpreted, only to sign and soon forget about the report as we move on to the next case? We diagnose diseases, but what 
steps do we take to probe and alleviate the social, economic and spiritual circumstances that sow the seeds of child abuse in the first place?

If all we do in the face of such abuse is fulfill the conditions of our employment, collect our paychecks and enjoy our comfortable lifestyles, how different are we really from the narrator's parents, who have gone up to church to revel in their righteousness?

Blake will have none of it. We may like to suppose that such pediatric patients find some modicum of happiness and joy because of us, but Blake suggests the opposite - that too often they do so in spite of us.

We may comfort ourselves with the notion that we have done them no injury, but even our sincerest well wishes avail little when vulnerable children remain in circumstances that lead to injury, illness and death. Blake is not suggesting that we can eliminate all threats to the health and well-being of children, but he is provoking us to ponder whether we have done as much as we could to address them.

In both poems, Blake paints a world where children suffer needlessly and mercilessly. He asks us to consider whether we have proved ourselves worthy of their trust or allowed them to remain in clothes of death, singing songs of woe.

Have each of us, as pediatric radiologists, truly done what we could to ensure that children are well-housed, wellclothed, well-fed, well-educated and, above all, well-loved? If not, then we share some measure of responsibility for their plight, no matter how many relative value units we have generated. Yet it is not our guilty plea that Blake seeks, but instead our hearts and action.

\section{References}

1. United States Department of Agriculture (2019) Cost of raising a child calculator. https://www.cnpp.usda.gov/tools/CRC_Calculator/ default.aspx. Accessed 31 July 2019

2. Pott P (1789) The chirurgical works of Percivall Pott. T Lowndes, London

3. Blake W (1794) Songs of innocence and experience. William Blake, London

Publisher's note Springer Nature remains neutral with regard to jurisdictional claims in published maps and institutional affiliations. 